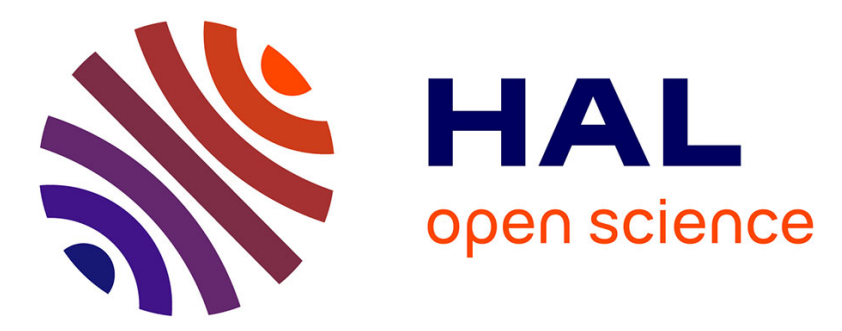

\title{
New temporal constraints on the rotation of the Peruvian central Andes obtained from paleomagnetism
}

\author{
O. Macedo-Sánchez, J. Surmont, C. Kissel, C. Laj
}

\section{To cite this version:}

O. Macedo-Sánchez, J. Surmont, C. Kissel, C. Laj. New temporal constraints on the rotation of the Peruvian central Andes obtained from paleomagnetism. Geophysical Research Letters, 1992, 19 (18), pp.1875-1878. 10.1029/92GL01070 . hal-03583717

\section{HAL Id: hal-03583717 https://hal.science/hal-03583717}

Submitted on 22 Feb 2022

HAL is a multi-disciplinary open access archive for the deposit and dissemination of scientific research documents, whether they are published or not. The documents may come from teaching and research institutions in France or abroad, or from public or private research centers.
L'archive ouverte pluridisciplinaire HAL, est destinée au dépôt et à la diffusion de documents scientifiques de niveau recherche, publiés ou non, émanant des établissements d'enseignement et de recherche français ou étrangers, des laboratoires publics ou privés. 


\title{
NEW TEMPORAL CONSTRAINTS ON THE ROTATION OF THE PERUVIAN CENTRAL ANDES OBTAINED FROM PALEOMAGNETISM
}

\author{
O. Macedo-Sánchez ${ }^{1,2}$, J. Surmont ${ }^{1}$, C. Kissel ${ }^{1}$ and C. Laj ${ }^{1}$
}

Abstract. New paleomagnetic data from middle Eocene to middle Miocene volcanic and plutonic formations of the Western Cordillera of Central Peru document a counterclockwise rotation of $11^{\circ} \pm 7.4^{\circ}$. This rotation, similar to previous results reported for the northern Peruvian margin, is post middle-Miocene in age. It is thus coeval with the acceleration of the Andean uplift and supports Isacks' model.

\section{Introduction}

Paleomagnetic results from Mesozoic formations have documented large counterclockwise rotations along the Central Peruvian Andes [Kono et al., 1985]. More recently, these results have been extended geographically from the Huancabamba deflection in the north to the Arica bend in the south and in time to Cenozoic formations [Mitouard et al., 1990; Macedo-Sánchez et al., 1992; Kissel et al., 1992]. These new results have established the remarkable coherence of the $15-20^{\circ}$ counterclockwise rotation of the Peruvian margin over a distance exceeding $1500 \mathrm{~km}$. Because this rotation is post-Eocene the authors have suggested that it might be related to the main uplift of the Central Andes, following a mechanism recently proposed by Isacks [1988]. According to this author, the crustal thickness of more than 70 $\mathrm{km}$ observed in the region of the Arica bend and the bending of the Bolivian orocline, result from along-strike variations in the amount of late Cenozoic shortening. Maximum shortening exists at $20^{\circ} \mathrm{S}$ latitude and decreases both northward and southward from the Arica bend, leading to counterclockwise and clockwise rotations of the Peruvian and Chilean margins respectively [Isacks, 1988]. Any precise description of the time evolution of this rotational pattern is however hindered by the lack of paleomagnetic results from Cenozoic and in particular Neogene formations. The only reliable and significant Cenozoic results available so far are limited to those from the Paleocene-Eocene formations in the Cajamarca region [Mitouard et al., 1990] and to a few sparse results of Paleocene to late Miocene age recently obtained in the Lima region [Macedo-Sánchez et al., 1992] and in the Arequipa region [Kissel et al., 1992]. Also, uppermost Miocene data obtained by Tsunakawa et al. [1987] in the Pisco, Nazca and Puno areas do not show any significant rotation and suggest that the Peruvian margin at this time was probably close to its present day position. On the other hand, the results obtained by Heki et al. [1985] on the late Miocene Ocros dyke swarm

\footnotetext{
'Centre des Faibles Radioactivités, CEA/CNRS, Gif-sur-Yvette, France.

2Instituto Geofísico del Perú, Casilla 3747 Lima 100, Perú.
}

Copyright 1992 by the American Geophysical Union.

Paper number92GL01070

0094-8534/92/92GL-01070\$03.00 indicating a significant counterclockwise rotation $\left(14^{\circ} \pm 5.5^{\circ}\right)$, have been seriously questioned by Beck [1988] as a result of a critical statistical re-examination of the data.

In this letter we report on new, more complete results obtained in the western Central Peru region from volcanic and intrusive formations of lower Eocene to middle Miocene age. These new paleomagnetic data are interpreted using the available reference poles from Stable South America (SOAM) and yield new constraints on the timing of the geodynamical evolution of the Peruvian margin during the Neogene.

\section{Geological setting and sampling}

The studied area is shown schematically in Figure 1. It comprises, from west to east, the Coastal Zone, the Western Cordillera and the High Plateaus. The geological and structural features of these zones have been described by Mégard [1978], Cobbing et al. [1981] and Jaillard [1987]. In the western sector of the Cordillera, the Mesozoic sedimentary and volcano-sedimentary sequences were intruded during late Cretaceous and Paleogene by a complex system of granites and granodiorites (the Coastal Batholith). They were then covered by the lavas and tuffs of the Calipuy Group the age of which ranges from 53 to $15 \mathrm{Ma}$ [references in Atherton et al., 1985]. East of the batholith, at least 5 episodes of plutonism,

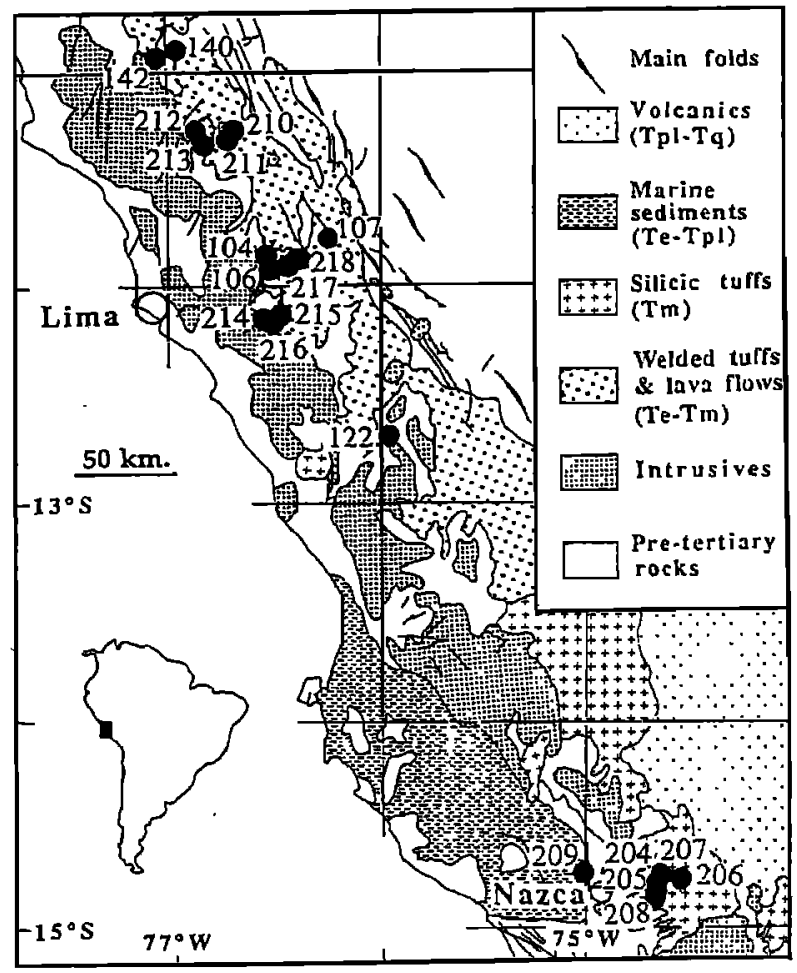

Fig. 1. Schematic geological map of the Westem Cordillera in Central Peru showing the locations of the sampling sites. 
generally granodioritic, have been documented. Their ages range from 41 to $3 \mathrm{Ma}$ [Soler and Bonhomme, 1988]. South of $13^{\circ} \mathrm{S}$, in the Western Cordillera, the Coastal Batholith cuts into late Jurassic to early Cretaceous schists and sandstones which are partially covered by the conglomerates and tuffs of the Nazca formation dated from 22 to $19 \mathrm{Ma}$ [Noble et al., 1979a].

The sampling has been conducted in 1988 and 1990 and the locations of the sites are shown on Figure 1. Six sites (PE204 to 209) were drilled in the siliceous tuffs of the Nazca formation. Three sites were sampled in the Surco (PE104 and 106) and the Catahuasi granites (PE122) dated at $21 \mathrm{Ma}$ and 24 Ma respectively [Mukasa, 1984; Beckinsale et al., 1985]. Site PE140 was sampled in the West Churin tonalitic stock dated at $30 \mathrm{Ma}$ [Cobbing et al., 1981; Soler \& Bonhomme, 1988], four sites (PE210 to 213) in the Acos small granitic intrusion considered as upper Eocene in age ( $37 \mathrm{Ma}$ [Soler, 1987]), two sites (PE217-218) in the dioritic postmetamorphic dykes dated between 39 and $31 \mathrm{Ma}$ [Vidal, 1987] and which cut the Mesozoic series. However, these last seven sites (PE140, PE210 to 213, PE217-218) may be older than their assumed ages as a consequence of a general reset of the $\mathrm{K} / \mathrm{Ar}$ ages in this area [Soler, 1987]. Finally, we sampled five sites in the Eocene to Miocene lavas and volcanoclastic series of the Calipuy Group (PE107, PE142 and PE214 to 216). Sites PE214 and PE216 were sampled in the undeformed tuffs at the very base of the formation, close to the place dated at $40-41 \mathrm{Ma}$ by Noble et al.[1979b].

A total of 226 cores has been obtained from these 21 sites dated as an average between 53 and $15 \mathrm{Ma}$. Clear bedding attitudes were observed for the tuffs and the ignimbrites, with tilts never exceeding $10^{\circ}$. No correction was used for the intrusives. Each core yielded 2-3 specimens allowing laboratory studies of the magnetic mineralogy and of the remanent magnetization.

\section{Magnetic Mineralogy and Paleomagnetic Results}

The magnetic mineralogy was investigated for at least one sample per site. Stepwise acquisition of isothermal remanent magnetization (IRM) indicates that saturation is virtually attained in all samples at fields lower than $0.3 \mathrm{~T}$. Thermomagnetic analyses, done on powder samples with an horizontal Curie balance, yield reversible heating and cooling curves with a Curie temperature close to $580^{\circ} \mathrm{C}$. This indicates that magnetite is the main magnetic mineral in the samples.

Small pellets made from powdered samples were analyzed with a Micromag alternating gradient force magnetometer. A typical hysteresis loop is shown in Figure 2a. There is a small paramagnetic contribution, shown by the slightly positive slope at high fields. After substraction of this component the saturation magnetization (Ms), the saturation remanence $(\mathrm{Mr})$, the coercive field $(\mathrm{Hc})$, and the coercivity of the remanence (Hcr) were calculated. The coercivities are all smaller than 80 $\mathrm{mT}$, which is consistent with the presence of magnetite. The ratios of the parameters (Figure $2 b$ ) indicate that the main fraction of the magnetization is carried by PSD-magnetite [Day et al., 1977].

Measurements were made with a three axis cryogenic magnetometer in a shielded room. Thermal demagnetization with a minimun of 12 steps from room temperature to the limit of reproducible results $\left(600^{\circ} \mathrm{C}\right.$ usually) was used throughout.

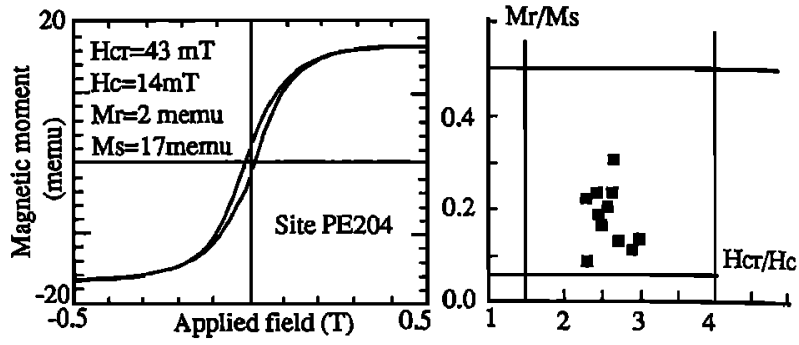

Fig. 2. A: Typical magnetic hysteresis loop; B: Magnetization and coercivity ratios from 11 representative volcanic and intrusive samples. All the values are grouped in pseudosingle domain area.

No significant changes of the low field susceptibility were observed during the thermal treatment, suggesting that the magnetic minerals are not seriously affected by the heating.

The natural remanent magnetizations (NRM) are typically of the order of $0.3 \mathrm{~A} / \mathrm{m}$. Generally the samples from the volcanic Nazca and Calipuy formation are characterized by a single stable component of magnetization isolated after 200$300^{\circ} \mathrm{C}$ (Figure 3a). Stable directions were determined from orthogonal demagnetization diagrams and the mean direction was calculated using Fisher's statistic [1953]. However, samples from the intrusive formations sometimes show two components of magnetization with overlapping blocking temperature spectra. In these cases, stable final directions and demagnetization circles were combined (Figure $3 b$ ) using the method of McFadden and McElhinny [1988].

The results are shown in Table I. There is a general good agreement between the data except for the sites from the Acos intrusive. In all the Acos sites (PE210 to 213) the presence of two antiparallel components close to the present day field gives evidence of a remagnetization (data from sites PE210 and 211 have been combined together for a better definition of the characteristic direction). This remagnetization could be related to the episode of metamorphism which has affected this region more recently than the lower Miocene [Soler, 1987]. Samples from site PE 209, drilled in the subhorizontal beds of the Miocene tuffs of the Nazca Formation are all characterized by two unexplained sub-vertical antiparallel components of magnetization. Therefore, sites PE209 to 213 were not considered in the final statistics. Because our sites are distributed in two separated areas (Lima and Nazca), two

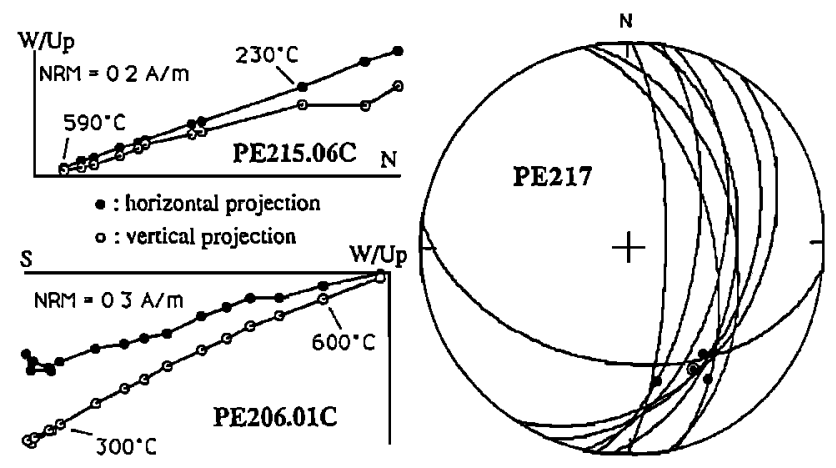

Fig. 3. Orthogonal projection diagrams (A) and equal area plot (B) of typical thermal behaviours. A: volcanic samples with a single stable component of magnetization. B: intrusive site showing both remagnetization circles and stable directions. 
mean paleomagnetic directions were calculated $\left(D=339.4^{\circ}\right.$; $\mathrm{I}=-26.6^{\circ} ; \alpha_{95}=8.8^{\circ}$ and $\mathrm{D}=343.1^{\circ} ; \mathrm{I}=-25.1^{\circ} ; \alpha_{95}=7^{\circ}$, respectively). The good agreement between these two directions and the absence of any documented shear zone between Lima and Nazca areas, led us to conclude that these two areas have been affected by the same rotation and have not rotated as independant crustal blocks. Accordingly, if all the data are combined together, the mean Eocene to middle Miocene paleomagnetic direction for the area studied here is: $\mathrm{N}=16 ; \mathrm{D}=340.5^{\circ} ; \mathrm{I}=-26.1^{\circ} ; \alpha_{95}=6.1^{\circ}$. When the two mean directions which are clearly outside the main group are rejected, we obtain a virtually identical mean regional direction with a smaller scatter: $N=14 ; D=341.4^{\circ} ; I=-27.3^{\circ} ; \alpha_{95}=$ $4.7^{\circ}$

\section{Discussion and Conclusions}

The interpretation of paleomagnetic results from the Andes is somewhat delicate, because of the lack of a continuous and precise Apparent Polar Wander Path (APWP) for SOAM. Taking into account the ages of the studied formations (Eocene to middle Miocene), we have referred all our results to the $40 \mathrm{Ma}$ mean pole calculated by Mitouard et al. [1990]. This pole does not differ significantly from the younger one (15 Ma) given by Valencio and Creer [1968]. The results are summarized in Table I and Figure 4 where the corresponding values of the rotation (R) and flattening (F) parameters calculated after Demarest [1983] are also reported.

TABLE I. Paleomagnetic results from Eocene to Miocene volcanic and intrusive formations of Central Peru.

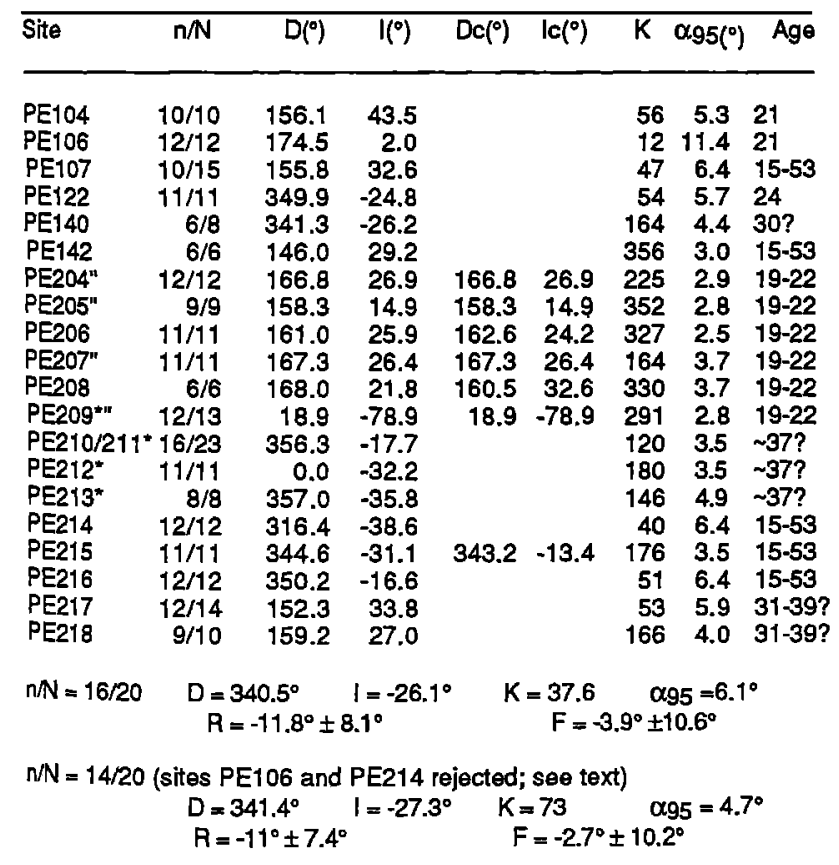

Mean directions are reported for each site before (D, I) and after bedding correction (Dc, Ic) (": sites with horizontal observed bedding attitude); K, Q95: Fisher's statistic parameters; the age of the rocks are given in Ma (?: sites which may be older than their assumed age); R, F: rotation and flattening parameters. ": sites rejected (see text).

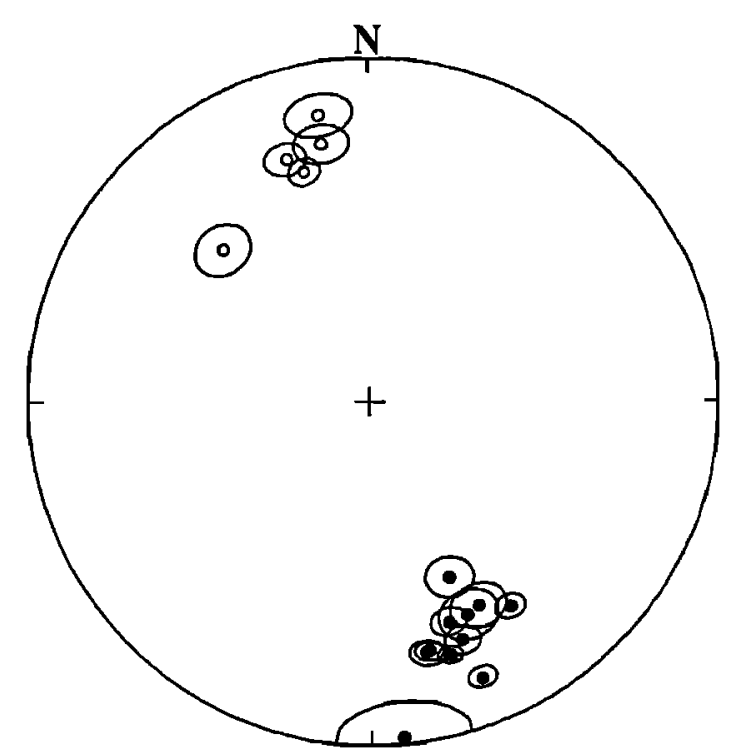

Fig. 4. Equal area projection of the reliable mean directions of the sites with their $95 \%$ angle of confidence.

There is a large incertainty on the $F$ parameter. Within these limits it does not indicate any significant latitudinal drift of the investigated area with respect to SOAM, in agreement with the autochthonous character of the studied formations.

The $\mathrm{R}$ parameter documents a significant post middle Miocene counterclockwise rotation of $11^{\circ} \pm 7.4^{\circ}$. The amplitude of this rotation is poorly defined largely because of the low accuracy on the position of the $40 \mathrm{Ma}$ reference pole $\left(\mathrm{A}_{95}=\right.$ $7.5^{\circ}$ ). This hinders a precise quantitative interpretation of the data. However, the mean amplitude of the rotation obtained for the Lima and Nazca areas is only $4^{\circ}$ less than the one of the rotation obtained from the Cretaceous data in the same area [Macedo-Sanchez et al.,1992]. It is also similar to the Paleogene paleomagnetic results reported from Norhern Peru [Mitouard et al., 1990]. The new results thus confirm the remarkable consistency of the post-Eocene rotation of the Peruvian margin from Northern to Central Peru over a distance exceeding $700 \mathrm{~km}$, and support Isacks' model for the uplift of the Central Andes.

In addition, according to the timespan covered by the new formations studied here, the rotation documented for Central Peru is much younger than previously supposed in MacedoSanchez et al. [1992]. The rotation is thus coeval with the acceleration of the Andean uplift documented by Sébrier et al. [1988]. It ended probably during middle-late Miocene, as the paleomagnetic data reported by Tsunakawa et al. [1987] seem to indicate. However, a better quantitative description of the rotation of the South American continental margin requires a significant improvement in the accuracy of the APWP for SOAM.

Acknowledgements: We wish to thank Dr. C. De Muizon for the technical support of the IFEA during the field trips and J. Jacay for his help during the sampling. The financial support has been given by the CEA, and the CNRS-INSU. CFR Contribution $n^{\circ} 1310$. Contribution CNRS-INSU-DBT (Thème Dynamique Globale) 460. 


\section{References}

Atherton, M. P., L. M. Sanderson, V. Warden., and W. J. McCourt, The volcanic cover: chemical composition and the origin of the magmas of the Calipuy Group, in Magmatism at a plate edge, the Peruvian Andes, edited by W. S. Pitcher, M. P. Atherton, E. J. Cobbing and R. D. Beckinsale, pp. 273-284, Halsted Press, New York, 1985.

Beck, M.E., Analysis of late Jurassic-Recent paleomagnetic data from active plate margin of South America, J. South Am. Earth.Sci., I, 39-52, 1988.

Beckinsale, R.D., A.W. Sanchez Fernandez, M.Brook, E.J. Cobbing, W.P. Taylor, and N.D. Moore, Rb-Sr whole rock isochron and $\mathrm{K}$-Ar age determinations for the Coastal Batholith of Peru, in Magmatism at a plate edge. the Peruvian Andes, edited by W. S. Pitcher, M. P. Atherton, E. J. Cobbing and R. D. Beckinsale, pp. 177-202, Halsted Press, New York, 1985.

Cobbing, E.J., W. S. Pitcher, J. J. Wilson, J. W. Baldock, W. P. Taylor, W. J. McCourt, and N.J. Snelling, Estudio geológico de la Cordillera Occidental del Norte del Perú, Boletín INGEMMET, Estudios Especiales serie D, $\mathrm{n}^{\circ} 10$, 252pp., 1981.

Day, R., M. Fuller, and V. A. Schmidt, Hysteresis properties of titanomagnetites: grains-size and compositional dependence, Phys. Earth Planet. Int., 13, 260-267, 1977.

Demarest, H. H., Error analysis for the determination of tectonic rotation from paleomagnetic data, J. Geophys. Res. 88 , 4321-4328, 1983.

Fisher, R. A., Dispersion on a sphere, Proc. R. Soc. 217. 195-305, 1953.

Heki, K., Y. Hamano, M. Kono, and T. Ui, Paleomagnetism of Neogene Ocros dyke swarm, the Peruvian Andes : implication for the Bolivian orocline, Geophys. J. R. Astr. Soc., 으, 527-534, 1985.

Isacks, B.L, Uplift of the central Andean plateau and bending of the Bolivian orocline, J. Geophys. Res., 93, 32113231,1988 .

Jaillard, E., Sedimentary evolution of an active margin during upper Cretaceous times: the north Peruvian margin from upper Aptian to Senonian, Geol. Rdsch, 76, 677-698, 1987.

Kissel, C., C. Laj, J. Surmont, O. Macedo-Sanchez, and P. Mitouard, South American active margin: Andean deflections and crustal thickening, Bull. Soc. géol. France., $163, n^{\circ} 4.371-380,1992$.

Kono, M., K. Heki, and Y. Hamano, Paleomagnetic study of the Central Andes: counterclockwise rotation of the Peruvian block, J. Geodyn., 2, 193-209, 1985.

Macedo-Sánchez, O., J. Surmont, C. Kissel, P. Mitouard, and $\mathrm{C}$. Laj, Late Cenozoic rotation of the Peruvian Western Cordillera and the uplift of the Andes, Tectonophysics, $\underline{205}, \underline{1-3}, 65-78,1992$.
McFadden, P.L., and M. McElhinny, The combined analysis of remagnetization circles and direct observations in palaeomagnetism, Earth Planet. Sci. Lett., 87, 161-172, 1988.

Mégard, F., Etude géologique des Andes du Pérou Central, Mémoires ORSTOM, 86, 310 pp., 1978.

Mitouard, P., C. Kissel, and C. Laj, Post-Oligocene rotations in southern Ecuador and northern Peru and the formation of the Huancabamba Deflection in the Andean Cordillera, Earth Planet. Sci. Lett. 98, 329-339, 1990.

Mukasa, S.B., Comparative $\mathrm{Pb}$ isotope systematics and zircon U-Pb geochronology for the Coastal, San Nicolas, and Cordillera Blanca batholiths, Peru, Thesis, 362 pp., University of Califomia, 1984.

Noble, D. C., Farrar and E. J. Cobbing, The Nazca Group of South-Central Peru: age, source and regional volcanic and tectonic significance, Earth Planet. Sci. Lett., 45, 80-86, 1979a.

Noble, D. C., E. H. McKee, and F. Mégard, Early Tertiary "Incaic" tectonism, uplift and volcanic activity, Andes of central Peru, Geol. Soc. Am. Bull. 90, 903-937, 1979b.

Sébrier, M., A. Lavenu, M. Fornari, and J. P. Soulas, Tectonics and uplift in Central Andes (Peru, Bolivia and Northern Chile) from the Eocene to present, Geodynamique 3 (1-2), 85-106, 1988.

Soler, P., Sur l'existence d'un épisode de métamorphisme régional d'âge Miocène inférieur dans la Cordillère Occidentale des Andes du Pérou Central, C. R. Acad. Sci. Paris, t 304, sér II, 911-915, 1987.

Soler, P., and M. G. Bonhomme, New K-Ar age determinations of intrusive rocks from the Cordillera Occidental and Altiplano of Central Peru: Identification of magmatic pulses and episodes of mineralization, J. South Am. Earth Sci, 1/2, 169-177, 1988.

Tsunakawa, H., H. Tanaka, K. Amano, and M. Kono, Paleomagnetic study of Late Miocene and Early Pliocene rocks from Southern Peru, Central Andes, I. Geomag. Geoelect. 39, 477-486, 1987.

Valencio, D.A. and K. M. Creer, El paleomagnetismo de algunas lavas cenozoicas de la República Argentina, Rev. Asoc. Geol. Arg. 23, 255-278, 1968.

Vidal, C., Kuroko-type Deposits in the Middle Cretaceous Marginal Basin of Central Peru, Econ. Geol., 82, 14091430, 1987.

C. Kissel, C. Laj, O. Macedo-Sánchez and J. Surmont, Centre des Faibles Radioactivités, Laboratoire mixte CNRSCEA, Avenue de la Terrasse, 91198 Gif-sur-Yvette Cedex, France.
(Received February 27, 1992;

revised May 5, 1992;

accepted May 6, 1992.) 